\title{
Simulering som pedagogisk metode i lærerutdanning
}

\author{
Marit Lindset, Ingvild Aune \\ Norges teknisk-naturvitenskapelige universitet - NTNU
}

\begin{abstract}
Abstrakt
Bakgrunn: Lærerstudenter skal inneha kompetanse innen ulike kommunikasjonsferdigheter for å være kvalifisert som lærer i skoleverket. Tilbakemeldingen fra studentene tyder på at de ønsker $\varnothing$ ving på virkelighetsnær kommunikasjon med relevans til skolepraksis Dette var utgangspunktet for et prosjekt som ble gjennomført på treårig yrkesfaglærerutdanningen i Trondheim, høsten 2018. Simulering ble tatt i bruk som undrevisningsverktøy med fokus på rollespill mellom elev og lærer.

Hensikt: $\AA$ unders $\varnothing$ ke studentenes erfaringer med bruk av simulering som pedagogisk metode i yrkesfaglærerutdanning.

Metode: 15 refleksjonslogger ble skrevet av førsteårstudenter ved yrkesfaglærerutdanningen, helse- og oppvekstfag. Analysen har ett fenomenologisk tilsnitt, og baserer seg på Malterud sin systematiske tekstkondensering.

Resultat: Studien viser at det var av betydning at forberedelsene startet tidlig i semesteret, der det ble presentert pensum med læringsutbyttebeskrivelser, og ett virkelighetsnært case. Studentene pekte på at debriefingsfasen var viktig i forhold til egen refleksjon og læring, og at de opplevde samlæring med medstudenter. Det ble meddelt at pensum ble synliggjort i rollespillet, og at studentene var tydelig på at $\emptyset$ ving var av nødvendighet for å bli trygg i lærerrollen. Studien viser at studentene $\varnothing$ nsket å anvende den kunnskapen de hadde ervervet til praksisfeltet.
\end{abstract}

Konklusjon: Studien viser at yrkesfaglærerstudentene opplevde nytteverdi av simulering som undervisningsmetode, og at denne kunnskapen hadde relevans til skolepraksis.

Emneord: Simulering, kommunikasjonsferdigheter, elevsamtale, læring 


\section{Innledning}

Lærerutdannere skal kvalifisere studenter til å bli kompetente lærere som er i stand til å takle de utfordringene som finnes i den norske grunnopplæringa (Kunnskapsdepartementet, 2013). I St.melding nr.30 Kultur for laring, fremheves det at skolens viktigste ressurs er lærere som er kompetente, engasjerte og ambisiфse på elevens vegne (Utdannings- og forskningsdepartementet, 2004, s. 24). Dette gjenspeiles i Forskrift for rammeplan for yrkesfaglærerutdanningen for trinn 813 som beskriver virkeområde og formål der utdanningen skal være av høy faglig kvalitet og med helhet og sammenheng mellom profesjonsfag, yrkesfag og praksis. Videre presiseres det at utdanningen må imøtekomme samfunnets og skolens behov (Kunnskapsdepartementet, 2013). Dagens videregående skoler sliter med stort frafall og elever med psykososiale plager (Statistisk sentralbyrå, 2019; Markussen \& Seland, 2012; Utvær \& Østern, 2014). Dette krever kompetente studenter som er rustet til å møte dagens utfordringer.

Yrkesfaglærerutdanningen i Norge er en treårig bachelorutdanning som dekker i alt åtte utdanningsprogrammer. Ved NTNU gis det studie i Helse- og oppvekstfag, Restaurant og matfag, Elektrofag, Bygg- og anleggsteknikk, samt Teknikk og industriell produksjon. Studentene har minimum fire års praksis i yrket. Studiet består av 180 studiepoeng fordelt på yrkesfagene og profesjonsfagene (yrkespedagogikk og yrkesdidaktikk), og innehar tre samlinger hvert semester (NTNU, 2019a). Ved yrkesfaglærerutdanningen i Helse- og oppvekstfag, har vi gjennom mange år prøvd ut ulike pedagogiske metoder. Pedagogiske metoder oppfattes som et vidt begrep og kan omfatte både spesifikke metoder og generelle undervisningsprinsipper som kjennetegnes av planmessige fremgangsmåter som baseres på visse pedagogiske prinsipper (Pettersen, 2005, s. 42). Ferdighetstrening er en pedagogisk metode, og innebærer aktiviteter rettet mot å utvikle, forbedre eller opprettholde ferdigheter, evner og/eller egenskaper (Salas \& Cannon-Bowers, 2001). I denne sammenheng menes øving av kommunikasjon- og relasjonsferdigheter, og knyttes til studentenes bevissthet om egne holdninger og verdier.

I dette prosjektet er simulering brukt som pedagogisk metode. Simulering handler om fenomener og aktiviteter som etterligner et klinisk miljø hvor en kan trene prosedyrer, ta beslutninger og drive kritisk tenking ved hjelp av rollespill, video og simulatorer (Ødegården, Struksnes, \& Hofmann, 2015, s. 13).

Internasjonal forskning innen lærerutdanning og annen profesjonsutdanning viser at simulering har et stort potensial for å vurdere profesjonell samtalekompetanse. Det oppleves motiverende for studentene og skaper effektive læringsmuligheter (Wiesbeck, Bauer, Gartmeier, Kiessling, Møller, Karsten, Fischer \& Prenzel, 2017). Annen forskning innen helsefaglige utdanninger viser at simulering brukt som pedagogisk verktøy forbereder studentene til å $\emptyset v$ vå realistiske situasjoner (Akselbo, Olufsen, Ingebrigtsen \& Aune, 2018; Brannan, White \& Bezanson, 2008; Breckwoldt, Gruber \& Wittman, 2014). Videre viser studier at simulering i sykepleieutdanningen kan erstattes av ferdighetstrening, og at samme læringsutbytte oppnås i forhold til ferdigheter og kunnskap (Celik, Ceylantekin \& Kilic, 2017; Forcina, Woodley \& Goodwin, 2018).

Ut fra litteraturs $\varnothing \mathrm{k}$ på simulering innen yrkesfaglærerutdanning, kan det tyde på lite forskning på området. Derimot er simulering som læringsverktøy her til lands mye brukt innenfor ulike helsefaglige utdanninger. Dette gjelder spesielt bachelor i sykepleie, der dette ofte blir nyttet som 
Øvinger på ulike medisinske prosedyrer (Ødegården, Stuksnes \& Hoffmann, 2015). Studier viser at sykepleiestudenter husker bedre og har større læringsutbytte når de simulerer det de skal lære. Videre opplever de å bli trygge i eget yrke (Rauen, 2004; Østergaard, 2004). Dette samsvarer med Akselbo et al., (2018) som viser til at sykepleiestudentene opplever at simulering er et realistisk og effektivt læringsverktøy som er nyttig for praksis og som gir grunnlag for refleksjoner. Derimot viser en studie at ferdighetstrening og simulering gir samme tilegnelse av kunnskap innen identifisering, prioritering og iverksetting av relevante sykepleietiltak (Bratås, Albriktsen, Eriksson \& Grønning, 2018).

Prosjektet tar utgangspunkt i emnet Kommunikasjon og samhandling (10 studiepoeng) som er knyttet til første studieår (NTNU, 2019b). Undervisningsmetodene har vært mange. Alt fra ren teoretisk undervisning til ulike studentaktiviteter, deriblant rollespill mellom elev og lærer. Tilbakemeldingene fra studentene viste at de ikke opplevde dette som reelt og virkelighetsnært. Dette var utgangspunktet for et prosjekt som ble gjennomført høsten 2018 ved Enhet for helsefaglig simulering ved NTNU, der simulering ble tatt i bruk som læringsverktøy. Fokuset på simuleringen var rollespill mellom to lærere og en elev. Caset tok utgangspunkt i en elev som hadde mange ulike utfordringer, både privat og i skolesammenheng. Det ble gjennomført live-streaming og videopptak av rollespillene.

Hensikten med denne studien var å undersøke studentenes erfaringer med bruk av simulering som pedagogisk metode i yrkesfaglærerutdanning. Det ble utarbeidet to forskningsspørsmål:

1. Hvilke erfaringer har studentene med simuleringens ulike faser? (briefing, scenario og debriefing).

2. Hvilke refleksjoner har studentene gjort seg i forhold til egne kommunikasjonsferdigheter?

\section{Teoretisk referanseramme}

Som fremtidige yrkesfaglærere er det av betydning at studentene innehar den kompetansen som arbeidslivet etterspør. Hvordan lærerutdannere legger til rette for læring er av betydning. I dette kapittelet presenteres ulike teoretiske perspektiver på hva som kan fremme læring ved bruk av simulering. Avslutningsvis presenteres Skaus (2017) modell for kommunikativ kompetanse.

Kolbs definisjon på læring bygger på erfaring, og han skriver: Learning is the process whereby knowledge is created through the transformation of experience (1984, s. 38). Ifølge Kolb er konkret erfaring grunnlag for læringsprosessen. Mennesket lærer av erfaring, man observerer, reflekterer og prøver å finne ut nye handlinger som i sin tur gir erfaringer å reflektere over. Det fungerer som en kontinuerlig runddans. Kolb argumenterer for at læring er en sirkulær prosess som omfatter fire læringstrinn.

I første trinnet tas det utgangspunkt i en deltakende konkret opplevelse, der man er åpen og villig til å engasjere seg. Det neste trinnet er reflekterende observasjon, der man fokuserer på de nye erfaringene fra så mange perspektiver som mulig. I tredje trinnet er utgangspunktet abstraksjon og generalisering. Alle dataene som er generert gjennom reflekterende observasjon er utgangspunkt 
for abstrakt begrepsliggjøring. Den lærende vil her fors $\emptyset$ ke å strukturere og generalisere erfaringene og overføre kunnskapene til andre sammenhenger. Ut fra den reflekterte erfaring blir dette utgangspunktet for det fjerde trinnet som er aktiv eksperimentering. Det er nå den lærende bruker det som han eller hun har lært til å gjøre nye beslutninger og handlinger. Deretter følger nye opplevelser og en ny runde i læringssirkelen (Kolb, 1984). Slik sett kan det sammenlignes med en spiral der læring foregår i en oppadstigende bølge (Tøsse, 2010).

De fire trinnene kan forstås som om de er integrerte i hverandre, slik at læring kan starte på hvilket som helst trinn. Hvis ikke alle prosessene er intakt, så vil man også miste potensialet for læring. Ifølge Kolb kan læring forstås best som en prosess, og ikke ut fra et produkt, eller det han kaller outcome (Kolb, 1984, s. 26). Kolb mener vi lærer hele tiden, og tilføyer at individets ideer eller tanker ikke er konstante. De formes og omformes hele tiden, og denne prosessen er tuftet på erfaringer.

Ser man mot Lave og Wenger, har de ulike perspektiver på læring. Begrepet situert laring knyttes til deltakelse i forskjellige sosiale relasjoner både i hverdagslivet og lærer-elev relasjon (Lave \& Wenger, 2003, s. 231). Det vil si at læring er forankret i en konkret situasjon, og at læring foregår i et sosialt fellesskap mellom personer. Dermed oppfattes læring som mer enn mentale oppgaver og problemløsning, men noe som relateres til individets miljø og at det er gjenkjennbart. Lave og Wenger oppfatter da læring som en sosial prosess som skjer mellom mennesker og ikke i mennesket. For at læring skal finne sted er det avgjørende at læringsmiljøet fungerer tilfredsstillende for den enkelte. Læringen er uformell og skjer uten pedagogiske rammer. Dermed kan man si at situert laering dreier seg om at all læring finner sted i en bestemt situasjon, og at denne situasjonen er av betydning for læringens karakter og resultat.

Et annet sentralt begrep ved læring som skjer i en situert virksomhet er legitim perifer deltakelse (Lave \& Wenger, 2003, s. 31). Lave og Wenger beskriver at begrepet skal forstås som en helhet, hvor legitim handler om måter å høre til på, og perifer om det å være plassert i en sosial verden. Deltakelse forstås som full deltakelse i et fellesskap (Lave \& Wenger, 2003, s. 37). De mener legitim perifer deltakelse er et analytisk perspektiv på læring. De understreker at det verken er en pedagogisk form eller en pedagogisk strategi eller undervisningsteknikk. Samtidig mener de at læring finner sted selv om man ikke setter det inn i en pedagogisk ramme. Det sentrale i prosessen er at lærlingen gradvis blir deltaker i fellesskapet. Lærlingen står ofte i starten i utkanten av fellesskapet. Dette på grunn av liten erfaring, men etter hvert vil han eller hun gradvis få den erfaringen som de andre i fellesskapet. Etter hvert blir de tatt opp som et fullverdig medlem i det sosiokulturelle fellesskapet. Begrepet legitim perifer deltakelse forteller også noe om relasjonen mellom lærlingen og veteranene. Hensikten er at lærlingen etter hvert skal observere, prøve og feile ut fra de arbeidsoppgavene som blir gjort.

Skaus (2017) modell for kommunikativ kompetanse tar utgangspunkt i personlig kompetanse, teoretisk kunnskap og yrkesspesifikke ferdigheter. Disse områdene danner en trekant der sidene er likeverdige og støtter hverandre. Hensikten er at læreren skal inneha likeverdig kompetanse på alle områdene. Personlig kompetanse rommer lærerens væremåte i samhandling med andre personer. Det synliggjør personenes egenskaper, holdninger og ferdigheter. Ifølge Skau (2017) inneholder den teoretiske kunnskapen kjennskap til begreper, modeller og teorier innen kommunikasjon. Yrkesspesifikke ferdigheter omfatter lærerens profesjonsutøvelse innen kommunikasjon. 


\section{Intervensjon/utprøving}

\section{Briefing - informasjon på forhånd}

Kullet bestod av 21 førsteårsstudenter ved yrkesfaglærerutdanningen. De var alle fagarbeidere med mange års yrkesbakgrunn innen helse- og oppvekstfag. Yrkene innbefatter helsesekretær, helsefagarbeider, apotektekniker, barne- og ungdomsarbeider, ambulansearbeider, portør, fotterapeut, tannhelsesekretær, ortopeditekniker og hudpleier (Utdanningsdirektoratet, 2019) Forberedelsene til prosjektet startet på andre samling, høstsemesteret 2018. Fasilitatorene, som begge var ansatt ved NTNU, henholdsvis faglærer ved yrkesfaglærerutdanningen og fasilitator/lærer ved Enhet for helsefaglig simulering, underviste i to timer om generell bruk av simulering som et læringsverktøy. Deretter var det gjennomgang av simuleringsprosessen som studentene skulle gjennomføre på simuleringsdagen. Dette innebar utlevering av case med situasjonsbeskrivelse som var virkelighetsnær og gjenkjennbar for studentene. Studentene fikk en detaljert gjennomgang av hva som skulle foregå på simuleringsdagen. Pensum ble oppgitt som en del av forberedelsen. I tredje samling var det satt av en dag til gjennomføring av simuleringen.

Caset omhandlet en 1. års- elev på Vg1, HO (Helse- og oppvekstfag). Eleven hadde ulike utfordringer med å takle sitt liv, både privat og i skolesammenheng. Det ble gitt en utførlig historikk om det som var aktuelt. Rollespillet tok utgangspunkt i et møte med eleven og to lærere, der den ene var kontaktlærer. Temaet er forankret i studieplan for yrkesfagene, emnet LYFH 1001 Kommunikasjon og samhandling (10 studiepoeng).

Læringsutbyttebeskrivelsene fokuserer på kommunikasjonsteorier, ulike kommunikasjonsferdigheter og refleksjoner i forhold til kunnskap, ferdigheter og generell kompetanse (NTNU, 2019b). De nevnte læringsutbyttene ble operasjonalisert til anvendbare relasjonsbyggende kommunikasjon. Studentene skulle forberede seg gjennom lesing av anbefalt litteraturliste, med spesielt vektlegging på aktiv lytting og nonverbal kommunikasjon. Aktiv lytting er en sammensatt ferdighet der man både er åpen, lyttende og tar i bruk et bredt spekter av kommunikasjonsformer i den hensikt å forstå den andre (Eide \& Eide, 2017; Røkenes \& Hanssen, 2012) Nonverbal ferdigheter er mer knyttet til kroppsholdning, Øyekontakt og bruk av stillhet (Eide \& Eide, 2017). Læringsutbyttebeskrivelsene ved yrkesfaglærerutdanning gjenspeiler læreplanen for Vg1 Helse- og oppvekstfag, der programfaget Kommunikasjon og samhandling omfatter bevisstgjøring av egen væremåte, og samhandling med ulike grupper i samfunnet (Utdanningsdirektoratet, 2019).

\section{Scenariet - gjennomføring}

Kullet ble delt i to med 10 studenter pr. gruppe. Gruppe 1 begynte på formiddagen, og gruppe 2 på ettermiddagen. Lærerteamet bestod av to fasilitatorer og en operatør som hadde ansvar for tekniske oppgaver, som eksempelvis video. Fasilitatorene ledet hver sin gruppe, og simuleringen ble gjennomgått to ganger pr. gruppe. Gruppene fulgte en tre- delt pedagogisk modell som tok utgangspunkt i briefing, gjennomføring av simulering og debriefing (Ødegården, Struksnes, \& Hofmann, 2015). I briefingen ble to simulerende (lærere) valgt ut via loddtrekking. Tidsrammen var årsak til at kun åtte studenter var delaktig i selve scenariet som ble gjennomført til sammen fire 
ganger. Markøren (eleven) var en innleid ungdom med skuespillererfaring. De resterende studentene var respondenter (observatører).

Simuleringen ble live- streamet til et klasserom der respondentene fikk i oppgave å skrive ned hva de ville ha gjort i samme situasjon. I tillegg skulle respondentene observere om studentene mestret relasjonsbyggende kommunikasjon. De simulerende og fasilitator var plassert i samme møterom, der fasilitator hadde kontakt med operatør via headset. Operatøren satt på et annet rom og hadde ansvar for live- streaming, lyd og videoopptak og ellers det som gikk på det tekniske. Tidsrammen var 30 minutter.

\section{Debriefing - samtale etter scenariet}

Etter gjennomføringen av scenariet ble hele studentgruppen samlet (markøren deltok ikke). De ble plassert $\mathrm{i}$ en ring, slik at alle fikk blikkontakt. Fasilitator hadde en veilederrolle med fokus på å legge til rette for studentenes refleksjoner slik at ny læring kunne oppstå (Kolb, 1984). De simulerende fikk først beskrive gjennomgangen av scenariet, og sine opplevelser av seansen. Deretter ble respondentene utfordret i forhold til hva de ville ha gjort i samme situasjon, med vektlegging på å begrunne sine utsagn. Videoklipp ble tatt i bruk flere ganger for å vise situasjoner som kunne gi nytteverdi for studentene. Tilslutt ble studentene utfordret på å reflektere over egen læring knyttet til læringsutbytteskrivelsene, og hva som kunne være av overføringsverdi som lærer på ungdomsskole og videregående skole. (Kunnskapsdepartementet, 2013). Tidsrammen var 30 minutter.

\section{Metode}

\section{Datasamling}

Etter at alle studentene hadde gjennomført simuleringen, enten som simulant eller respondent, fikk de tilbud om å delta i studien. For å få svar på studentenes erfaringer av simuleringen, skrev studentene refleksjonslogger som ble utført en uke etter gjennomføringen. Studentene skulle reflektere over følgende:

3. Reflekter over dine erfaringer du har gjort deg etter simuleringen. Ta utgangspunkt i: a) Briefing (informasjon på forhånd) b) Scenariet (gjennomføring) c) Debriefing (samtale etter scenariet) d) Respondentrollen/simulerenderollen e) Fasilitator d) Omgivelsene rundt scenariet.

4. Reflekter over hva du vil ta med deg fra simuleringen inn i praksisstudiet.

5. Hvilke tanker har du gjort deg i forhold til å ta i bruk simulering som læringsmetode på yrkesfaglærerutdanningen?

Refleksjonsloggenes lengde ble angitt til omlag 600 ord. Av 20 studenter var det 15 studenter som $\emptyset$ nsket å delta i studien. Utvalget bestod av kvinner i alderen 26- 49 år. Gjennom studien ble forskningsetiske prinsipper fulgt (Kvale, Brinkman, Andersen \& Rygge, 2015). Studien ble inn- 
meldt og godkjent av Personvernombudet for forskning og Norsk senter for forskningsdata (med saksnummer 732126). Studentene skrev under på samtykkeerklæring, og fikk informasjon om hva dette innebar. Alle refleksjonsloggene var anonymiserte.

\section{Data analyse}

Datamaterialet ble analysert gjennom systematisk tekstkondensering ut fra Malterud (2013) sine beskrivelser. Analysemetoden er inspirert av Giorgi's (2009) fenomenologiske analyse. Formålet med den fenomenologiske analysen er utvikling av kunnskap om informantenes erfaringer og livsverden innenfor et bestemt felt. Man leter etter essenser og setter egen forforståelse i parentes i møtet med data (bracketing). Gjennomføringen av analysens fire trinn ble gjort: (1) Refleksjonsloggene ble lest nøye gjennom for å få et helhetsinntrykk. Det ble valgt å analysere alle punktene under ett. I alt fem temaer kom til syne. Eksempelvis: opplevelse av nytteverdi $i$ forberedelsesfasen, veiledningen fikk oss til å reflektere, larte mest av det medstudenter gjorde, opplevelse av å bli utfordret av både fasilitator og medstudenter. (2) Meningsbærende enheter ble identifisert med utgangspunkt i de ulike temaene i første fase. Ulike kodegrupper ble deretter utviklet. Eksempelvis: god informasjon for simuleringen, refleksjonens betydning, realisme gir laringseffekt. (3) Fra hver kodegruppe ble meningen trukket ut ved å kondensere innholdet i de meningsbærende enhetene. I denne prosessen fremstod ulike subgrupper: å lare av medstudenter, bevisst egen varemåte, videreføring av kunnskap. Det ble identifisert tekstelementer der disse kodene fremstod. (4) Tekstbitene ble nå hentet tilbake, og de viktigste emnene i refleksjonsloggene ble samlet til en sammenfattende beskrivelse eller hentet ut igjen med direkte sitater fra de ulike refleksjonene som studentene hadde beskrevet. Sammenfatningen av essensen i hver av de kondenserte kodegruppene i trinn 3 ble utviklet, og de følgende kategorier ble utformet og danner grunnlaget for underavsnittene i resultatkapitlet: Briefingens betydning, Debriefingens betydning og Anvendelsen av simulering.

\section{Resultat}

Ut fra dataene ble det utkrystallisert tre kategorier: I kategorien Briefingens betydning (informasjon på forhånd) presenteres studentenes erfaringer av lærerteamets arbeid og engasjement. I kategorien Debriefingens betydning (samtale etter scenariet) beskrives studentenes refleksjoner i henhold til hva de hadde lært av scenariet. I kategorien Anvendelsen av simulering er fokuset nytteverdi av simulering, som kan ha overføringsverdi til hvordan de kan ta i bruk erfaringen med simulering i samtale med elever.

\section{Briefingens betydning/ ... vi var godt forberedt}

Det ble påpekt fra studentene at informasjonen, som ble gitt av lærerne, bidrog til mer kunnskap og trygghet i den videre simuleringsprosessen. Et annet moment, som ble løftet opp av studentene, var lærernes engasjement. Mange pekte på at denne positiviteten smittet over på dem, og gjorde dem 
mer beredt til å gå inn i en ukjent læringssituasjon. Studentene meddelte at de grudde seg for simuleringen, men ved informasjon og tid til spørsmål ble dette mer ufarliggjort. Dette ble formulert slik av en student: Vi forberedte oss allerede på andre samling. Larer har fått oss til å reflektere rundt dette tema. Hun jobbet med at alle forstod hva simulering var, og at ulike følelser kunne oppstå.

Studentene pekte på at pensumet innen emnet Kommunikasjon og samhandling ble opplevd teoretisk og tungt. De erfarte derfor at det var en fordel å få kjennskap til pensum med konkretisering av læringsutbyttene i god tid. Dermed kunne de forberede seg og sette seg inn i fagstoffet i forkant. Den samme erfaringen meddelte studentene med utlevering av caset som tok utgangspunkt i selve scenariet. Tilbakemeldingene fra studentene viste at de opplevde situasjonsbeskrivelsen som virkelighetsnært og realistisk. Det ble pekt på at innholdet i caset harmoniserte med egne erfaringer fra skolepraksis som de hadde gjennomført før denne samlingen. Studentene pekte på at de kunne kjenne igjen innholdet i situasjonsbeskrivelsen fra egne erfaringer i skolepraksis. Det ble meddelt fra en student: Vi fikk servert en case som jeg tenkte var både dagsaktuell og spennende. En annen student formulerte det slik: Vi fikk god informasjon om hva som skulle skje, og en trygghet for hvordan dagen var lagt opp.

\section{Debriefingens betydning}

Studentene erfarte under debriefingen at fasilitator hadde en betydelig rolle med å lede samtalen i etterkant av scenariet. Det ble pekt på at fasilitator var engasjert, ga trygghet og stilte tydelige spørsmål. Både respondenter og simulanter opplevde å bli utfordret til refleksjon. En student illustrerte det slik: Hun stilte mange gode spørsmål som fikk meg til å reflektere over de ulike scenariene under simuleringen, og vi ble tvunget til å tenkelfølge med, og til å sette ord på det $i$ ringen.

Studentene pekte på stor nytteverdi av samlæring. De løftet opp dialogens og refleksjonens betydning som verdifull i forhold til egen læring og utvikling som fremtidige lærere. Det ble pekt på at medstudenter ga gode reflekterende tilbakemeldinger. Flertallet av studentene hadde en responderende rolle, mange ga likevel uttrykk for at de hadde lært mye av å observere medstudenter. En student illustrerte dette: Synes det er larerikt å høre hvor forskjellig folk hadde opplevd det hele, og hvor forskjellige ting de hadde lagt merke til. Men ikke alle hadde samme erfaring. En annen student formulerte det slik: Jeg følte spørsmålene ble lagt frem på en feil måte, og at det kom mye kritikk til oss. Ble lagt mye vekt på hva vi gjorde galt i kommunikasjonen, men lite hva som var rett i simuleringen. Noen studenter pekte også på at det ble mye fokus på hva simulantene hadde utført $i$ et scenarium, og meddelte at medstudentene ikke ønsket å gi negative tilbakemeldinger, men at de følte at noen studenter opplevde dette som kritikk.

Studentene erfarte at den forberedte teorien ble tydeliggjort i scenariet. De opplevde å ha knagger å henge det gitte pensumet på, og erfarte at dette var nyttig som fremtidige lærere. Dette ble formulert slik: Stort utbytte av denne måten å jobbe på. Det er tydelig å se hvor viktig det er med relasjonsbyggende kommunikasjon sammen med elev. 
Studentene opplevde at rollespillet var både realistisk og virkelighetsnært, og synliggjorde kommunikasjonsferdighetene tydeligere enn andre metoder. Det ble påpekt at de opplevede å leve seg inn i situasjonen og glemte at dette var et rollespill. En student illustrerte dette:

Her tenker jeg at slik simulering er en unik måte å få et lite innblikk i en lærer sin hverdag utenom undervisningssituasjonen. Både ved å være simulant og ved å være respondent blir vi kastet ut i situasjonen som krever at vi har lært mye om å kommunisere. Andre metoder, både skriftlig og rollespill, vil ikke gi tilsvarende læringseffekt fordi de ikke har samme realisme. Simulering er etter min vurdering en unik læringsmetode.

\section{Anvendelsen av simulering}

Studentene pekte på konkrete kommunikasjonsferdigheter som de opplevde som nyttig overføringsverdi til praksisfeltet. De meddelte eksempelvis bruk av pauser i en samtale, hvordan stille gode spørsmål, aktiv lytting, kroppsspråk, stemmebruk, non verbal kommunikasjon, empati og hvordan fange elevens oppmerksomhet. I tillegg ble det nevnt viktigheten av at eleven var i sentrum. Flere pekte på at de aldri hadde gjennomført en elevsamtale og at dette ble mer tydeliggjort. En student formulerte det slik: Kommer garantert til å huske denne seansen hvis jeg skal ha en elevsamtale i fremtiden, og vil ta med meg alle tipsene.

Studenter meddelte at de ble mer bevisst på egen væremåte i møte med andre mennesker. Etter simuleringen hadde de reflektert over sin egen kommunikasjon. De opplevde at de kommuniserte på en lite pedagogisk måte, og de ga lite rom for at andre fikk innpass i en samtale. Det ble tydeliggjort at de etter simuleringen hadde erfart at det kan være nyttig å ta i bruk kommunikasjonsferdigheter som kan bedre relasjonen og gi trygghet i samtalen. Studentene pekte på at dette var en bevisstgjøring som de ønsket å videreføre i all samhandling med andre personer, og ikke bare til elever. De poengterte at dette var nyttige erfaringer som de ønsket å få en bevisst holdning til, og hadde overføringsverdi til praksis. En student formulerte det slik:

Jeg ser tydeligheten i de ulike kommunikasjonsteknikkene, og hvilke betydninger det kan ha i de ulike situasjonene. Jeg sitter igjen med en god følelse, og gode erfaringer til å ta med meg videre både som yrkesfaglærer, men også som helsepersonell.

Andre momenter som ble løftet opp var nytteverdien av å øve på kommunikasjonsteknikker som de får bruk for i møte mellom lærer og elev. Ut fra skolepraksis tidligere i høst, opplevde studentene at det er ulike utfordringer knyttet til elevgruppen i videregående skole. Det kom frem at studentene hadde liten undervisningserfaring. De fleste kom fra yrker innen helsefag, og det ble meddelt at det var helt nytt å ha profesjonelle samtaler med ungdom. Det ble også pekt på at når de var i skolepraksis så fikk de kun observere elevsamtaler sammen med kontaktlærer. Studentene formidlet at Øving på ulike kommunikasjonsferdigheter ga trygghet og mestring, og at simulering av elevsamtale i studiet var en læringsmetode som de opplevde som nyttig å ta med seg inn i lærerrollen. De ønsket å være mest mulig forberedt til samtaler med elever før de skulle ut i praksisfeltet. En student sa: 
Jeg tenker at det er en styrke for oss som fremtidige lærere å kunne øve oss i realistiske, men ufarlige situasjoner før vi skal jobbe med sårbare ungdommer som trenger trygge, gode relasjoner. Jeg ønsker å være en god lærer, og da trenger jeg muligheten til å øve.

\section{Diskusjon}

Hensikten med denne studien var å undersøke studentenes erfaringer med bruk av simulering som pedagogisk metode i yrkesfaglærerutdanning.

Studentene ga uttrykk for å være godt forberedt til simuleringen. De meddelte at innholdet i undervisningen på 2. samling hadde relevans og var virkelighetsnær. I St.meld. nr.16 (2016-2017) påpekes det at læringsutbyttebeskrivelsene må gi meningsfull informasjon om hva studentene skal lære, og at utdanningen bør ha relevans til arbeidslivet (Kunnskapsdepartementet, 2016). For at læring skal finne sted er det avgjørende at læringsmiljøet fungerer tilfredsstillende for den enkelte (Lave \& Wenger, 2003). Kolb (1984) påpeker at det er av betydning at lærer tar hensyn til at studentene befinner seg på ulike ståsteder i læringssirkelen. Dette betyr at lærer må gi studentene utfordringer i forhold til individuelt kunnskapsnivå. Dette kan videreføres med at studentenes læringsutbytte bedres når de deltar aktivt, ser helheten, sammenheng og relevans (Aamodt, Prøitz, Hovdhaugen \& Stensaker, 2007). Dette støttes av Illeris (2012) sin samspillsprosess der lærer fors $\emptyset$ ker å tilrettelegge for studentens tilegnelsesprosess gjennom å tydeliggjøre både pensum og læringsutbytte beskrivelser. Ser man mot Dewey (1938/1997) understreker også han betydningen av at undervisningen skal oppleves som nyttig og ta utgangspunkt $i$ samfunnets krav og utvikling. Dette støttes av en studie der studentene opplevde teoriundervisning uten sammenheng med praksis som ikke relevant (Sylte \& Jahanlu, 2017).

Resultatene i studien viste at studentene ble påvirket av lærerens iver og positivitet. Dette kan tolkes dithen at motivasjonen ble trigget til økt kunnskap. Ifølge Illeris (2012) forbinder han motivasjon med at drivkraftsdimensjonen må integreres for at de innholdsmessige resultatene av læring skal manifestere seg. Dette støttes av forskning som viser at gode undervisere har positiv interaksjon med studentene, har høye forventninger til dem og sørger for et godt læringsmiljø (Hattie, 2015).

Studentene løftet spesielt opp fasilitators rolle i refleksjonsprosessen i debriefingsfasen. Fasilitator har en svært viktig rolle i simuleringen i forhold til både å lede gruppen og gi innspill til refleksjon, jamfør Zigmont, Kappus og Sudikof (2011). Illeris (2012) peker på at begrepet refleksjon dreier seg både om ettertanke og om speiling. Ved ettertanke reflekterer man nærmere over noe, mens man ved speiling, speiler sin opplevelse eller forståelse av noe i sitt eget selv eller i en annens reaksjon. Ser man mot Kolb (1984) argumenterer han for at refleksjon ligger implisitt i de fire læringstrinnene, der konkret erfaring er grunnlag for læringsprosessen. Studentene ble utfordret av fasilitator til å reflektere over hva de hadde erfart og observert, med utgangspunkt i rollespillet. Ifølge Kolb (1984) kan læring starte på hvilket som helst trinn. Hvis ikke alle prosessene er intakte, så vil man også miste potensialet for læring. Denne parallellen kan man også trekke i forhold til at studentene var forskjellige både når det gjaldt kunnskap og erfaringer. Dette kan påvirke prosessen i forhold til hvor man befinner seg i sirkelen (Kolb, 1984). Erverving av kunnskap 
er da avhengig av den enkeltes ståsted i sirkelen. Men for at læring skal skje, må refleksjon ligge til grunn for hvert trinn. Slik sett ble det viktig at fasilitator utfordret studentene slik at de kunne bevege seg fritt i læringssirkelen avhengig av den enkeltes kunnskapsnivå (Kolb, 1984). I så måte bør fasilitator være bevisst at studentene kan føle stress og angst ved å prestere foran andre, enten i rollespill, samtalen i etterkant eller videoinnslag (Cantrell, Meyer \& Mosack, 2017). Studier viser at dette blir verre dess flere medstudenter som er involverte (Najjar, Lyhman \& Miehl, 2015).

Studentene erfarte at de lærte av hverandre ved å sette ord på hva de ville ha gjort i samme situasjon. De reflekterte over hvordan de ville ha utført dette i skolepraksis. Ifølge Lave og Wenger (2003) er kunnskap forankret i konkrete situasjoner, og læring foregår i et sosialt felleskap der man lærer av hverandre. Kolb (1984) argumenter for at det er ulike måter å se verden på, og legger til at læringsidealet er vanskelig å oppnå. Det kreves at studenten både har evne til å handle, og samtidig er i stand til å reflektere.

Resultatene fra studien viste at studentene erfarte at situasjonsbeskrivelsen i caset hadde overføringsverdi til praksisfeltet. Ved at studentene hadde roller som respondenter eller simulerende, hadde de alle med seg sine tanker, følelser og meninger som involveres i erfaringslæring (Kolb, 1984). Slik sett kan det tyde på at studentene etter simuleringen ervervet seg kunnskap som ble mer tydeliggjort og avgjørende for læringsprosessen (Illeris, 2012; Kolb, 1984; Dewey, 1938/1997). Det ble pekt på at øving på kommunikasjonsferdigheter knyttet til et realistisk rollespill, og bevisstgjøring av egen væremåte ga et stort læringsutbytte i forhold til reelle elevsamtaler som fremtidige lærere. Dette ble fremhevet som viktig siden studentene ikke fikk øve på elevsamtaler i praksis, og at veileder i praksis involverte studentene lite i kommunikasjonsprosesser med elever. For å utvikle seg som fagperson, er det av betydning at studentene får $\emptyset$ ving i kommunikasjonsferdigheter.

Studentene tydeliggjorde at øving på kommunikasjonsferdigheter var av avgjørende betydning for å utføre en god jobb i praksis. De hadde et viktig poeng ved at kompetente lærere skal mestre ulike utfordringer som de møter i grunnopplæringa, jamfør St.meld.nr.16 (Kunnskapsdepartementet, 2016). I et debattinnlegg fra Utdanningsnytt (Aarset, 2018) stilles det spørsmål om lærerutdannere prioriterer $\varnothing$ ving av kommunikasjonsferdigheter og forbereder studentene på kontaktlærerrollen. For å være en kompetent lærer er det ikke nok med kun teoretisk kunnskap, men studentene må også inneha yrkesspesifikke ferdigheter og personlig kompetanse (Skau, 2017). Den som фnsker å utvikle sin kommunikative kompetanse, må arbeide med alle sidene ved den og bringe dem i samklang (Skau, 2017, s. 86). Dette viser viktigheten av at lærerinstitusjonene har et ansvar med å legge til rette for at studentene får tilstrekkelige kommunikasjonsferdigheter, slik at de er kompetente til å møte ulike utfordringene i videregående skole (Lindset, Rismark \& Lyngsnes, 2016). Studier viser at god relasjon mellom lærer og elev er sentralt for elevenes motivasjon og læring (Hughes \& Chen, 2011; Katz, Kaplan \& Gueta, 2010; Wentzel, Battle, Russell \& Looney, 2010). Forholdet mellom lærer og elev har betydning for elevenes læringsutbytte, derfor bør øving innen kommunikativ kompetanse styrkes.

Ut fra resultatene, kan det tolkes dithen at studentene var i stand til å innta samspilldimensjonen som omfatter handling, kommunikasjon og samarbeid (Illeris, 2012). I dette legges det at studentene prøvde å oppnå en sosial og samfunnsmessig integrasjon som de fant akseptabel, samtidig som de utviklet sin sosialitet. Ifølge Lave og Wenger (2003) er nettopp samhandling med medstudenter 
avgjørende for læringsutbyttet. Studentene pekte på at simulering som læringsmetode ga et godt læringsutbytte sammenlignet med andre metoder. De begrunnet dette med at de opplevde rollespillet både som realistisk og virkelighetsnært. Dette er sammenfallende med andre studier som er gjennomført (Akselbo et al., 2018; Rauen, 2004; Østergaard, 2004).

Denne studien har noen begrensninger. De fleste studentene fikk tildelt respondentrollen; slik sett fikk de ikke oppleve hvordan det var å gå inn i lærerrollen. Dette kan ha påvirket resultatet. Ved senere bruk av simulering som pedagogisk metode kan det være en fordel å gjennomføre to rollespill parallelt, slik at alle studentene kan gå inn i simulantrollen. En lærer ved utdanningen var også fasilitator under simuleringen. Dette kan ha påvirket hva studentene beskrev i sine refleksjonslogger. Resultatene baserer seg på et lite utvalg studenter. Nye studier med et bredere utvalg, eksempelvis studenter i ulike studieårsenheter vil kunne gi mulighet for andre eller sammenfallende resultater. Det kan også være av interesse å undersøke om simulering som pedagogisk metode gir bedre kommunikasjon mellom lærer og elev i praksisfeltet.

\section{Konklusjon}

Studien viser at yrkesfaglærerstudentene opplevde nytteverdi av simulering som undervisningsmetode, og at denne kunnskapen hadde relevans til praksisfeltet. Resultatene viser at det er av vesentlig betydning at studentene startet tidlig med forberedelser. Her løftet studentene opp viktigheten av å få utlevert pensum med læringsutbyttebeskrivelser og en realistisk og virkelighetsnær case. Dette motiverte til videre læringsprosess. Studentene uttrykte at de hadde behov for å Øve på kommunikasjon mellom lærer og elev, og pekte på at фving på ulike kommunikasjonsferdigheter ga både mestring og trygghet. De uttrykte at teorien ble mer tydeliggjort, ble mer bevisst egen væremåte, og de lærte av hverandre. Studentene pekte på at fasilitator hadde en viktig rolle i forhold til deres refleksjon og læring. Det ble uttrykt at andre undervisningsmetoder innenfor temaet kommunikasjon ikke ga tilsvarende læringseffekt fordi de ikke hadde samme realisme som simulering. Simulering som pedagogisk metode bør også være av interesse for andre utdanningsprogram innenfor lærerutdanning.

\section{Forfatterbiografi}

Marit Lindset er universitetslektor ved Institutt for samfunnsmedisin og sykepleie, NTNU. Hun har lang erfaring med undervisning og veiledning ved bachelorutdanningen yrkesfaglærer i helseog oppvekstfag. Hennes forskningsområder er knyttet til veiledning, akademisk skriving og simulering innen temaet kommunikasjon. Hun er opptatt av videreutvikling av læringsaktiviteter og tverrfaglig samarbeid mellom ulike utdannings-program. Hun har bakgrunn som sykepleier og mangeårig lærer i videregående skole.

Ingvild Aune er dosent i jordmorfag, og studieprogramleder ved jordmorutdanningen, NTNU. Hennes forskningsområder er innenfor svangerskap, -fødsel og barseltid og omfatter tema som 
fremming av en normal fødsel, kvinnens fødselsopplevelse, relasjonell kontinuitet i jordmoromsorg, kvinners opplevelser av ultralydundersøkelser i svangerskapet, samt jordmødres ideologi og utøvelsen av faget. Hennes forskningsområdet er også innenfor utdanning av jordmorstudenter og tverrfaglighet i utdanning.

\section{Referanser}

Akselbo, I., Olufsen, V., Ingebrigtsen, O. \& Aune, I. (2018). Simulation as a learning method in public health nurse education. Public Health Nursing, (36), 226-232. https://doi.org/10.1111/phn.12560

Brannan, J., White, A. \& Bezanson, J. (2008). Simulator effects on cognitive skills and confidence levels. Journal of Nursing Education, 7(11), 495-500. https://doi.org/10.3928/01484834-20081101-01

Bratås, O., Albriktsen, T. O., Eriksson, U. \& Grønning, K. (2018). Effekt av simulering for tilegnelse av kunnskap i sykepleierutdanningen- en RCT-studie. Uniped, 4(41), 469-483. https://doi.org/10.18261/issn.1893-8981-2018-04-08

Breckwoldt, J., Gruber, H. \& Wittman, A. (2014). Simulation learning. I S. Billett, C. Hartei \& H. Gruber (red.). International handbook of research in professional and practice based learning (s. 673-698). Dordrecht: Springer. https://doi.org/10.1007/978-94-017-8902-8_25

Cantrell, M. L., Meyer, S. L. \& Mosack, V. (2017). Effects of Simulation on Nursing Student Stress: An Integrative Review. Journal of nursing education, 56(3), 139-144. https://doi.org/10.3928/01484834-20170222-04

Celik, Y., Ceylantekin, Y. \& Kilic, I. (2017). The evaluation of simulation maket in nursing education and the determination of learning style of students. International Journal of Health Sciences, 11(3), 74-79. Hentet fra https://www.ncbi.nlm.nih.gov/pmc/articles/PMC5604268/

Dewey, J. (1938/1997). Experience and education. New York: Simon and Schuster. Hentet fra https://archive.org/details/ExperienceAndEducationJohnDewey/page/n27/mode/2up

Eide, H. \& Eide, T. (2017). Kommunikasjon i relasjoner. Personorientering, samhandling, etikk. (3. utg.). Oslo: Gyldendal Akademisk.

Forcina Hill, J. M., Woodley, L. \& Goodwin, M. (2018). Simulation to prepare graduate nursing students for clinical faculty role. Nursing Education Perspectives, 39(5), 319-321. https://doi.org/10.1097/01.NEP.0000000000000304

Giorgi. A. (2009. The descriptive phenomenological method in psychology: Amodified husserlian approach. Pittsburg: Duquesne University Press.

Hattie, J. (2015). The applicability of Visible Learning to higher education. Scholarship of Teaching and Learning in Psychology, 1(1), 79-91. http://dx.doi.org/10.1037/st10000021

Hughes, J.N. \& Chen, Q. (2011). Reciprocal effects of student-teacher and student-peer relatedness: Effects on academic self efficiacy. Journal of Applied Developmental Psychology, 3(2), 278-287. https://dx.doi.org/10.1016\%2Fj.appdev.2010.03.005

Illeris, K. (2012). Laring. Oslo: Gyldendal akademisk. 
Katz, I., Kaplan, A. \& Gueta, G. (2010). Students' Needs, Teachers' Support, and Motivation for Doing Homework: A Cross Sectional Study. Journal of Experimental Education, 78(2), 246 267. https://doi.org/10.1080/00220970903292868

Kolb, D. (1984). Experiential Learning: Experience as the Source of Learning and Development. Englewood Cliffs, NJ: Prentice-Hall.

Kunnskapsdepartementet (2013). Forskrift om rammeplan for yrkesfaglarerutdanning for trinn 813. Hentet fra https:/www.regjeringen.no/globalassets/upload/kd/vedlegg/rammeplanen/yrkesfaglaererutda nning.pdf

Kunnskapsdepartementet (2016). Meld. St. 16 (2016-2017). Kultur for kvalitet i høyere utdanning. Hentet fra https://www.regjeringen.no/no/dokumenter/meld.-st.-1620162017/id2536007/sec1

Kvale, S., Brinkmann, S., Anderssen, T. M. \& Rygge, J. (2015). Det kvalitativeforskningsintervju (3. utg.). Oslo: Gyldendal akademisk.

Lave, J. \& Wenger, E. (2003). Situeret laring og andre tekster. København: Reitze.

Lindset, M., Rismark, M. \& Lyngsnes, K. (2016). Læreres møte med elever i yrkesopplæringens fellesfag, Tidsskriftet FoU i Praksis, 10(2), 45-59. Hentet fra https://utdanningogpraksis.no/index.php/up/article/view/1783

Malterud, K. (2013). Kvalitative metoder i medisinsk forskning. (3.utg.). Oslo: Universitetsforlaget.

Markussen, E. \& Seland, I. (2012). A redusere bortvalg-bare skolens ansvar? En unders $\phi k e l s e$ av bortvalg ved de videregående skolene i Akershus fylkeskommuneskoleåret 2010-2011.

Rapport 6. Oslo: NIFU. Hentet fra https://nifu.brage.unit.no/nifuxmlui/bitstream/handle/11250/280856/NIFUrapport2012-6.pdf?sequence=1\&isAllowed=y

Najjar, R. H., Lyman, B. \& Miehl, N. (2015). Nursing students experiences with high- fidelity simulation. International Journal of Nursing Education Scholarship, 12(1), 27-35. https://doi.org/10.1515/ijnes-2015-0010

NTNU (2019a). Yrkesfaglarerutdanning- Studiets oppbygning. Hentet fra https://www.ntnu.no/studier/byrk/oppbygning

NTNU (2019b). LYFH 1001 Kommunikasjon og samhandling. Hentet fra https://www.ntnu.no/studier/emner/LYFH1001\#tab=omEmnet

Pettersen, R. C. (2005). Kvalitetslæring i høgere utdanning. Innføring i problem- og praksisbasert didaktikk. Oslo: Universitetsforlaget.

Rauen, C. A. (2004). Simulation as a Teaching Strategy for Nursing Education and Orientation in Cardiac Surgery. Critical Care Nurse, 24(3), 46-51. https://doi.org/10.4037/ccn2004.24.3.46

Røkenes, H. O. \& Hanssen, P. H. (2012). Bare eller briste. Kommunikasjon og relasjon i arbeid med mennesker. (3. utg.). Oslo: Fagbokforlaget.

Salas E., \& Cannon-Bowers J.A. (2001). The science of training: A decade of progress. Annual Review Psychology 52, 471-499. https://doi.org/10.1146/annurev.psych.52.1.471

Skau, G. M. (2017). Gode fagfolk vokser. Personlig kompetanse i arbeid med mennesker (5.utg.). Oslo: Cappelen Forlag.

Statistisk sentralbyrå (2019, 13. juni). Gjennomføring i videregående opplaering. Hentet fra https://www.ssb.no/vgogjen 
Sylte, A. L. \& Jahanlu, D. (2017). Profesjonsrettet lærerutdanning for yrkesfag - dagens undervisning og opplevelse av relevans. Skandinavisk tidsskrift for yrker og profesjoner $i$ utvikling, 2(2). https://doi.org/10.7577/sjvd.2010

Tøsse, S. (2011). Historie, praksis, teori og politikk. Oslo: Tapir akademiske forlag.

Utdanningsdirektoratet (2019). Laereplan i felles programfag $i$ Vgl helse- og oppvekstfag. Hentet fra https://www.udir.no/k106/HSF1-01/Hele/Kompetansemaal/kommunikasjon-ogsamhandling

Utdannings- og forskningsdepartementet (2004). Meld. St. 30 (2003-2004). Kultur for laering. Hentet fra https://www.regjeringen.no/no/dokumenter/stmeld-nr-030-2003-2004Lid404433/?ch=1

Utvær, B.K. \& Østern, A-L. (2014). Sårbare unge i kunnskapssamfunnet. I C. Haugen \& T. A. Hestbek, T. A. (red.), Pedagogikk, politikk og etikk. Demokratiske utfordringer og muligheter i norsk skole, (s. 275- 286). Oslo: Universitetsforlaget.

Wentzel, K. R., Battle, A., Russell, S. L. \& Looney, L. B. (2010). Social supports from teachers and peers as predictors of academic and social motivation. Contemporary Educational Psychology, 35(3), 193-202. https://doi.org/10.1016/j.cedpsych.2010.03.002

Wiesbeck, A. B., Bauer, J., Gartmeier, M., Kiessling, C., Möller, G. E., Karsten, G., Ficher, M.R. $\&$ Prenzel, M. (2017). Simulated conversations for assessing professional conversation competence in teacherparent and physician-patient conversations. Journal for Educational Research Online.9 (3), 82-101. Hentet fra https://www.pedocs.de/volltexte/2018/15302/pdf/JERO_2017_3_Wiesbeck_et_al_Simulated _conversations.pdf

Zigmont, J. J., Kappus, L. K. \& Sudikoff, S. N. (2011). Theoretical foundations of learning through simulation. Seminar Perinatology, 3(2), 47-51. https://doi.org/10.1053/j.semperi.2011.01.002

Ødegården, T., Struksnes, S. \& Hofmann, B. (2015). Pasientsimulering i helsefag- en praktisk innføring. Oslo: Gyldendal Akademisk.

Østergaard, D. (2004). National Medical Simulation training program in Denmark. Critical Care Medicine, 32(2), 58-60. https://doi.org/10.1097/01.CCM.0000110743.55038.94

Aamodt, P. O., Prøitz, T. S., Hovdhaugen, E. \& Stensaker, B. (2007). Laringsutbytte i høyere utdanning: En drøfting av definisjoner, utviklingstrekk og måleproblemer. Oslo: NIFU STEP. Rapport 40. Hentet fra https://nifu.brage.unit.no/nifu-xmlui/bitstream/handle/11250/280627/NIFUrapport200740.pdf? sequence $=1$ \&isAllowed $=\mathrm{y}$

Aarset, L. B. (30.11.2018). Utdanningsnytt. Hvorfor forbereder vi ikke lærerstudentene på kontaktlærerrollen? Hentet fra https://www.utdanningsnytt.no/grunnskole-laererstudiet-laereryrket/hvorfor-forbereder-viikke-laererstudentene-pa-kontaktlaererrollen/141717 